\title{
Excess length of stay due to methicillin-resistant Staphylococcus aureus (MRSA) infection at a large Swiss hospital estimated by multi-state modelling
}

\author{
M Macedo-Vinas,', G De Angelis, C Fankhauser, E Safran, J Schrenzel, D Pittet, S Harbarth \\ From International Conference on Prevention \& Infection Control (ICPIC 2011) \\ Geneva, Switzerland. 29 June - 2 July 2011
}

\section{Introduction / objectives}

Excess LoS related to MRSA infections increases hospital costs. Current statistical approaches to estimate excess LoS suffer from methodological limitations including time-dependant bias. We aimed to estimate excess LoS due to MRSA infections in acute care wards at the University of Geneva Hospitals using a novel multistate modelling strategy.

\section{Methods}

During 2009, 167 MRSA-infected and 25766 MRSAuninfected control patients were included in a multistate model where occurrence of MRSA infection was the time-dependent exposure and discharge or death was the study endpoint. Infections were stratified by anatomical site. Excess LoS was extracted computing the Aalen-Johansen estimator of the matrix of transition probabilities. 95\% confidence intervals were derived by bootstrap re-sampling. Multivariate Cox regression analysis (adjusted for sex, age, cancer and diseases of the skin and subcutaneous tissue and of circulatory and digestive system) was used to assess the independent effect of MRSA infection on excess LoS.

\section{Results}

Median LoS of infected patients was 30 days compared to 6 days for controls. In the multistate model, excess LoS for all MRSA infections was 11.5 days (95\% CI, 7.915). The highest impact was due to bacteraemia $(20$ days; 95\% CI 8-32) and skin and soft tissue infections (18.8 days; 95\% CI 6.1-31.6). The multivariate Cox proportional hazards model confirmed that nosocomial

Hopitaux Universitaires de Geneve, Geneva, Switzerland
MRSA infection significantly reduced the likelihood of discharge (adjusted HR 0.69; 95\% CI 0.59-0.81).

\section{Conclusion}

Using a novel multistate modelling strategy to avoid time-dependant bias, MRSA infection at any anatomical site proved to significantly prolong $\operatorname{LoS}$ in acute care.

\section{Disclosure of interest}

None declared.

Published: 29 June 2011

doi:10.1186/1753-6561-5-S6-089

Cite this article as: Macedo-Vinas et al:: Excess length of stay due to methicillin-resistant Staphylococcus aureus (MRSA) infection at a large Swiss hospital estimated by multi-state modelling. BMC Proceedings 2011 5(Suppl 6):089.

Submit your next manuscript to BioMed Central and take full advantage of:

- Convenient online submission

- Thorough peer review

- No space constraints or color figure charges

- Immediate publication on acceptance

- Inclusion in PubMed, CAS, Scopus and Google Scholar

- Research which is freely available for redistribution

\section{(Ciomed Central}

( 2011 Macedo-Vinas et al; licensee BioMed Central Ltd. This is an open access article distributed under the terms of the Creative Commons Attribution License (http://creativecommons.org/licenses/by/2.0), which permits unrestricted use, distribution, and reproduction in any medium, provided the original work is properly cited. 